paradox first given point by Sir Arthur Lewis that, when it comes to foreign aid, the industrialized nations have most to offer in the form of agricultural produce.

\section{Room in Paris}

THe Collège de France is openly staking a claim on the site in Paris that will be vacated, possibly in five or six years, when the Ecole Polytechnique moves out to Palaiseau in the south-west suburbs. The Collège has been in Paris since its foundation in 1530 by Francis I as part of an attempt to break the stranglehold of the schoolmen at the Sorbonne by creating a community of scholars independent of the politics of the University of Paris. The Collège de France, like many other academic institutions which are similarly placed in the hearts of capital cities, now finds the pressures of modern life-and particularly the nonacademic demand for space-an increasing source of frustration. But, for one reason or another, moving out of town is unthinkable. It is no wonder that the professors of the Collège de France should be so excited by the prospect of a vacant lot in the gift of the French Government and only a few hundred metres from their present building that they have allowed themselves to express their yearnings in public.

Professor Louis Leprince-Ringuet put the claim of the Collège in an article in Le Monde on July 20 . In the nature of things, the argument goes, the fifty or so professors who make up its membership must divide their time between research and teaching. But because their interests span the whole field of scholarship, they need facilities of all kinds. The humanists need access to the Louvre and the Bibliothèque Nationale, while the scientists-roughly twenty of them-must have their own laboratories and research assistants. Professor Leprince-Ringuet is eloquent about the great advantages which come from a system which requires distinguished men of diverse interests to work closely together in the same premises, and cites as an example the way in which Joliot-Curie and Robert Courrier worked on the study of thyroxine, using radio-iodine as a tracer. He argues quite openly that the Collège de France is "probably the only institution of higher education whose presence in Paris is almost essential", and goes on to say that, even though the College has no ambition to own large cyclotrons or nuclear reactors, it would gain enormously if the scientists could be gathered on to the same site rather than be scattered as at present up and down the Rue des Écoles and even farther away. Scholars everywhere will be interested to see how successfully it will be possible to sustain this claim on real estate in the centre of a capital city.

\section{Doctors in Distress}

MEDICAL manpower and utilization have been areas of debate and concern in Britain for a long time, but debate has often taken the place of action. In a pamphlet Medical Manpower the Office of Health Economics points out that more than 40 per cent of the hospital doctors in 1964 were born outside the country, while during the 1950 's more than 5,000 doctors, the equivalent of one quarter of graduates of British medical schools, emigrated from Britain and did not return.
Coupled with these quantitative statistics, the study discusses the qualitative problems facing the hospitals; specialization has become increasingly necessary because of the complexity of modern surgical techniques and the need for medical and non-medical specialists in areas such as radiotherapy and heart surgery. Another problem facing the hospitals is the recruitment of junior staff; the incentive for staying at a hospital has usually been to reach the final goal of a consultant post. With far more registrars than consultants, more and more young doctors have gone directly into general practice so that, between 1961 and $1964,1,000$ out of the 1,100 increase in the numbers of junior hospital staff were born outside the British Isles. The Office of Health Economics blames this situation on three factors: a large error in forecasting the future need for doctors, much greater emigration from Britain than was expected or has been admitted, and a failure to take account of the rapid technological progress and changing pattern of medical care over the past twenty years when modifying medical education.

In the early 1950 's there was a widespread belief in Britain that too many doctors were being trained. The Willink Committee was set up in 1955 to investigate this situation and, based on a population growth rate of 4.5 per cent-which in fact turned out to be 7.0 per cent-and assumptions about the growth of hospital staff which have proved to be half the actual growth, the committee held that student intake should be reduced by 10 per cent. This decision was reversed in 1961, but the effects are still felt in the present situation. Migration remains a major problem, yet the Council of the British Medical Association in 1958 reported that net emigration among doctors and dentists "can be considered of no special significance". Finally, while the specialized training and skills necessary for hospital staff have become less and less related to the community care demanded of the general practitioner, medical education and training have done little to recognize the variation in training that these distinct paths call for.

The study concludes that, while small advances are being made - closer links are growing between hospitals, general practitioners and local authorities-and automation and qualified auxiliaries are avenues to be explored, for the present the most pressing need is to increase the efficiency of the manpower now available.

\section{Three Years of Data}

The National Bureau of Standards in the United States has just celebrated the third anniversary of the National Standard Reference Data System, which is the formal name for a programme intended to build up critical compilations of scientific data. Sensibly enough, the work is being co-ordinated with that of standards institutions outside the United States, most effectively by a committee of ICSU with a staff in Washington. Inevitably, however, the contribution of the United States is a very large part of the whole, and not simply because, in June 1963, the then director of the U.S. Office of Science and Technology said that the "intent is to provide an articulated system of activities under such co-ordination and direction as to ensure a compilation of data meeting quality standards, and also to maintain continuous policy guidance of the system at the level of the Executive Office". The 